International Journal of Social Science and Economic Research

ISSN: 2455-8834

Volume:05, Issue:10 "October 2020"

\title{
WOMEN'S AND MEN'S LANGUAGE IN CONVERSATION
}

\author{
NGUYEN THI THU \& TRAN QUOC VIET
}

Lecturer at Vietnam Trade Union University \& Hanoi Metropolitan University

DOI: 10.46609/IJSSER.2020.v05i10.008 URL: https://doi.org/10.46609/IJSSER.2020.v05i10.008

\begin{abstract}
How women and men use language in conversation, what differences, how genders use and affect language, are the main focuses of the study. The data with 9 different texts is collected from official seminars between Vietnamese students and Swedish teachers, so language use here is quite formal. The data is observed; the findings of speakers are compared and discussed to find out the differences within quantitative method. The main result of the study is that the men take up more linguistic space and dominate the topical shifts in the conversation, but they take little care to polite norms, politeness strategies when they have conversation with women, however; in this aspect, women take prominent role. They are nice to talk to and they know how to listen and give good impression. The finding is consistent with previous research within the field of gender and language. In conclusion, gender differences with cultural influence causes different language uses when men and women involve in communication process.
\end{abstract}

Keywords: men, Women, Conversation, Language, Students.

\section{Introduction}

\subsection{Rationale for the study}

Communication plays a very important part in business in general and in everyday life conversations in particular. The communication process would not be as rich without language and the communication process may be boring without the participation of men and women who have key roles in every conversation. People are social beings in society so the language people use will be closely linked to and influenced by sex and gender, and language variation is well known through the linguistic behaviour of different genders.

A great deal of attention has been paid to language and gender. The concept of gender is different from sex: sex describes a biological distinction, while gender refers to differences of behaviour through socialization. Extensive study and research has been carried out in this field to investigate how men and women use language differently in different social contexts. How men 


\section{International Journal of Social Science and Economic Research}

ISSN: $2455-8834$

Volume:05, Issue:10 "October 2020"

and women talk has arguably been demonstrated to show differences in communicative styles. Furthermore, in speech communities, men's language styles have been reported as assertive and competitive, while women's have been seen as supportive and co-operative. These will be discussed in more detail in the theoretical background below. The differences can be seen both in written and spoken language and differences in talking are presented in this essay.

\subsection{Aim of the study}

The purpose of this paper is to find out differences in language use between Vietnamese men and women in speech in English from the point of view of three main aspects: male dominance, politeness strategies and changing the topic in conversation. This study investigates linguistic differences between the sexes: what features speakers use as typically male or female, whether men use language to dominate women, the communicative techniques women apply in conversations and topic shifts between men and women's talk through chat logs and transcriptions of seminars.

\subsection{Outline of the study}

The study will be presented in five major parts:

1. Introduction gives the rationale, the aim, and the outline of the study

2. Theoretical background: this section examines the theoretical aspects relating to materials and data

3. Methodology and Data

4. Data analysis and Results

5. Conclusion: gives a short summary of the study and some advice

\section{Theoretical background}

While the most obvious function of language is to communicate information, language also contributes to two other equally important functions: to establish and maintain social relationships, and to express and create the social identity of the speaker (Tannen, 1990). These functions may be recognized less often because information is conveyed not as much through what we say, as through how we say it. In other words, information is conveyed as much by how we compose our utterances as through the precise character of our thought. This is certainly true of gender. 


\section{International Journal of Social Science and Economic Research}

ISSN: $2455-8834$

Volume:05, Issue:10 "October 2020"

In communication, it is said that men are from Mars, women are from Venus (Gray, 1992). Because of this opposition, women and men demonstrate different ways of communicating. Men and women establish separate speech communities, which has led to research in sex differences in conversation. Sex is acknowledged as nature and reproduction, while gender reflects an art, a cultural achievement (Coulmas, 2006). The differences between the sexes not only lie in physiological differences, but in culture and the social construction of genders. Gender is not something we are born with, and not something we have, but something we do and something we perform (Eckert and McConnell-Ginet 2003:10). In this section, the study focuses on three aspects where men and women may use the typical functions of language differently: dominance, politeness strategies and changing the topic of conversation.

\subsection{Dominance}

The dominance approach refers to power, inequality and linguistic differences in women's and men's speech. Dominance can be recognized through mixed-sex conversation, women often talk to gain confirmation, for men, however, talking is a way to gain status and keep it. So dominance can be defined as men's typical feature.

\subsection{Politeness strategies}

Politeness describes behaviours that are "somewhat formal and distant" (Holmes, 1995:4). She points out that to express politeness is to express respect to another whom you talk to, and to avoid offending them. According to Brown and Levinson (1978; 1987), politeness is defined as addressing the notion of "face", which includes "negative face"- the desire not to be imposed upon, and "positive face"- the desire to be liked and complimented, and avoid imposing on others or threatening others' face. An apology is an example of negative politeness; while to express warmth to another is positive politeness, such as greetings, friendly address terms, expressions of concerns and compliments. In the communication process, men and women carry out politeness strategies in term of compliments, apologies and back-channel support.

Compliments are closely linked to politeness in that they cater for positive face needs. The more frequently compliments are given, the more polite speakers are. In order to test whether women or men are more polite in speech acts and how they express politeness differently, Holmes (1995) investigated the interaction between men and women in New Zealand. She found that women gave and received more politeness forms than men did, such as compliments and apologies. Holmes (1989) reports the results of the complimentary behavior study (see table 1): women use compliments to each other significantly more often than they do to men (FemaleFemale, 248), account for $51.2 \%$ while they give compliments to male far fewer than (FemaleMale, 80), account for only 16.5. However; men are opposite, they give compliments to 
different sex partners (Male - Female, 112) with 23.1\% much higher than men do to each other (44) with only $9.1 \%$. And that most compliments concerned appearance (your skirt is really nice), ability (well done), or possessions (I like your new car). It was discovered that women received more compliments and gave more compliments than men, and that women of higher status received more compliments than men of higher status.

\section{Table 1}

\begin{tabular}{|l|l|l|}
\hline Compliment- Recipient & Number & $\%$ \\
\hline Female- Female (F-F) & 248 & 51.2 \\
Female- Male (F-M) & 80 & 16.5 \\
Male- Female (M-F) & 112 & 23.1 \\
Male- Male (M-M) & 44 & 100 \\
Total & 484 & 9.1 \\
\hline
\end{tabular}

Compliments and analyzed according to sex of participants (Homes, 1989: 198)

Holmes (1995) points out that the so-called "polite language behaviours" in society are very much based on the interactions of women as norms. In other words, women's language behaviours are taken as conforming to the social dimension of politeness together with social standards; men's in tendency is the opposite. Politeness is "dispensable between intimates in private" (Holmes, 1995:194). No matter whether they are at home or in public, men do not often apply kinds of politeness into conversation, especially to apparent equals in status (like to men). On the other hand, women, in general, are much more likely to express positive or negative politeness in interaction.

However, it is not always the case, O' Barr and Atkins (1980) in their courtroom studies tested politeness norms like hedges. They found that these features were not all present in women's speech. Some professional females who had appeared as expert witnesses use less “women's language" than some males; while some unemployed or blue-collar males had higher scores than women. Some characteristics of women's speech are affected by the setting and the topic, and the type of interacting in a courtroom makes them behave differently from everyday life conversations. The distinction in O' Barr and Atkins's research can be explained by different context and speakers' educational level. 
When it comes to apologies, the result closely paralleled compliments: women apologized more than men did, and they were also apologized to more often than the men (see table 2). Women take the highest proportion of $56.3 \%$ (99) when they make apologies to other women but only $18.2 \%$ (32) when they do so with men. On the other hand; men make apologies to other men with the least proportion of $8.5 \%$ (15), but the rate is twice higher when they do so with women $17.0 \%$ (30).

The following table shows the degree and frequency of making apology between single-sex groups and mixed-sex groups.

\section{Table 2}

\begin{tabular}{|l|l|l|}
\hline Apologizer- Victim & Number & $\%$ \\
\hline Female- Female (F-F) & 99 & 56.3 \\
Female- Male (F-M) & 32 & 18.2 \\
Male- Female (M-F) & 30 & 17.0 \\
Male- Male (M-M) & 15 & 8.5 \\
Total & 176 & 100 \\
\hline
\end{tabular}

Apologies analyzed according to sex of participants (Homes, 1989: 198)

Brown (1980) also tested the hypothesis that women are more polite than men in a Mayan community in Mexico. She studied in Tenejapa, a Mayan community in Mexico, and found that women used more politeness indicators, and they had "characteristically feminine strategies" (Brown, 1980:129). She relates this to Treadmill's argument, which indicates that women use more prestige language forms because they are conscious of their status. It seems reasonable to predict that women, on average, will talk more formally and polite since women are culturally of an inferior status and "high level politeness is expected from inferior to superiors" (Brown, 1980:112).

Women's language is considered as a standard variety with a wide range of linguistic variants. If men see conversation as asymmetrical, women, on the other hand, look at conversation from a more symmetrical viewpoint. As a result of frequently having variable social roles, accompanied with different speaking styles, women's language seems to have more in common with standard varieties. Coulmas (2006: 82) argues "women control a wider range of 


\section{International Journal of Social Science and Economic Research}

ISSN: $2455-8834$

Volume:05, Issue:10 "October 2020"

linguistic variants and are thus superior in terms of their sociolinguistic competence. They have also been shown to surpass men in fluency, listening comprehension, speaking, vocabulary, sentence complexity, and spelling while men seem to have reading disabilities and other dyslexic problems" Women see conversation basically as a co-operative activity; while men see it as a competitive one.

The asymmetrical relationship between men and women seems to be due to the fact that language users speak in different and distinctive ways that reflect their sex. Women focus on the need of others to regulate their talk and enjoy intimate, "affective oriented talk". On the contrary, men seem to appraise the circumstances in terms of its potential for themselves; they tend to focus on the public, "referentially orientated talk" (Holmes, 1995). It seems that when there is an unequal relationship between male and female, the powerful conversing form then represents the male competitive exchange.

Similar to compliments and apologies, back-channel support is involved in conversations as a way to promoting the talking process. Wareing also adds that women are better at communicating than men: "women are often more active than men in supportive roles in conversation" (2005: 88). Having conversation with other people, women pay much attention to conversation by giving much back-channel support such as (oh, really? Yeah, hmm) which indicate attentive listening, women see these kinds of minimal responses as signals of " $\mathrm{I} \mathrm{am}$ listening" but men are the opposite. They produce less back-channel support and they are likely to ignore or challenge their partner's utterances. Men interpret back-channel support as the meaning of "I agree". Yule (2004: 225) stated: "In cross-gender interaction, the absence of backchannels from men tends to make women think the men are not paying attention to them. The more frequent production of back-channels by women leads men to think that the women are agreeing with what they're saying."

To sum up, women are often more polite than men and they know how to apply communicating techniques into conversation, men are different, they don't often pay attention to these techniques, but they try to lead women to intended topics by frequently changing the topic of conversation.

\subsection{Changing the topic of conversation}

Social scientists have paid a great deal of attention to how much men and women talk, but have paid little attention to what they talk about. Research in the tradition of conversation analysis suggests that transitions between topics of conversation should be considered in this regard and that social status can affect whose topics are developed and whose are lost. Topics introduced 


\section{International Journal of Social Science and Economic Research}

ISSN: $2455-8834$

Volume:05, Issue:10 "October 2020"

into a conversation have different life expectancies depending on whether they are introduced by a man (almost all survive) or a woman (less than half are taken up and continued).

Having conversations with women, men try to dominate the topics of the conversation; and on the other hand, they tend to reduce the topics that women want to develop (Klann \& Delius, 1987). Holmes (1995) reports that in some contexts such as formal meetings, it is usually men who dominate the talking time and women see it as inherently unfair, and as evidence of male control. This kind of differences between women and men's communicative styles can be explained as results of historical inequalities in power and status.

Fishman (1978, 1983) coded successful and unsuccessful topic changes among three heterosexual couples over 12.5 hours of talk. She discovered that men's topics succeeded $96 \%$ of the time, while women's succeeded only $36 \%$ of the time. It can be said that men and women understand topics differently: for example, men tend to define topics quite narrowly, resulting in abrupt topic shifts, while women tend to develop topics progressively and gradually.

Besides topic shifts, during the conversation between men and women, we can look at different typical topics between men and women. While women's topics are about their family, their emotions, their friendships, men, on the other hand, as Wareing (2004: 89) argues "prefer more impersonal topics, often based on factual or technical knowledge, such as football, cars or home improvements".

In conclusion, men and women bring different features and styles to conversations. In order to maintain harmonious inter-gender relationships and reach a deeper understanding of language and gender, it is necessary to take a very detailed look at gender behavior in different situations. Furthermore, more attention needs to be paid to social and linguistic differences within gender groups to improve the equality between men and women and understanding of how and when gender is involved in interaction and how it affects women's and men's ways of speaking.

\section{Methodology and Data}

\subsection{Methodology}

The subjects who participated in this study are adults. The ages of the subjects range from 25 to 48 years of age, there are 26 married people but 5 single ones. They are all university-educated, coming from different provinces in Viet Nam. There are 22 women and 9 men of whom 6 men and 16 women are from the North, 5 women are from the Central, only one woman together with 3 men is from the South. They have known each other for some time because they are classmates and most of them are teachers of English (27 people), a man is working in the field of education 


\section{International Journal of Social Science and Economic Research}

ISSN: $2455-8834$

Volume:05, Issue:10 "October 2020"

and only three women are working in different area (a woman is working for a project, two women are working for a company). The study has been based on qualitative research methods: observing chat logs and transcripts of seminars, then different features in the speech of men and women in different situations are counted and compared. In the transcripts, there are proper names of subjects, but these names are replaced by student or teacher and enclosed sex (male or female) to guarantee the impersonality. In addition, suitable data is elicited and illustrated by tables and charts to describe and analyze it according to theoretical background and aim stated before.

The analysis will focus more specifically on the three main points: dominance, politeness strategies and changing the topic of conversation. The dominance approach is conducted by observing conversations in mixed groups through chat logs, then it is measured from the frequency of appearance of men and women, and the times men refer to women (known as references). Politeness strategies are carried out by counting the amount of back-channel support men and women use in conversations and listing the times men and women make apologies and say thank you. Finally, changing the topic of conversation is implemented by collecting the sentences that don't relate to topic of conversation to prove that men prefer changing the topic to women do.

\subsection{Data}

The manner that the study has gone about collecting materials is through chat logs and transcripts of seminars. These chat logs and transcripts are collected from Fronter in rooms 3003 and 3009 with the number of 9 different texts.

\section{Data Analysis and Results}

\section{Data Analysis}

\subsection{Male dominance}

\subsubsection{Frequency of appearance}

Many linguists acknowledged that in conversation, it is always men who hold the floor. The theories illustrate those differences of linguistic features result from the asymmetrical power between men and women in mixed-sex speech acts. Tannen (1990) refers to symmetry and asymmetry as one of the biggest influences on inter-gender communication, while Wareing (2004) emphasizes men's interruptions to women. Crawford (1995) indicates that in mixed-sex speech acts it is always the men that dominate the whole process. Several other writers such as Lackoff (1975), Holmes (1995), and Coates (1986) have admitted that men's language is seen as 
superior to women's. In conversations men feel free to disagree with women speakers. On the other hand, women tend to express more supportive and encouraging responses than men do, to agree rather than disagree with the speakers. In a lot of investigations, it has been found that the way men use language to be socially dominant over women.

Comparing the way men and women talk to each other through seminars, it is realized that the dominance doesn't really happen when the conversation is taken place in single-sex interactions (between men-men or women-women). But the distinction arises clearly between mixed-sex conversations. The study demonstrated that the average number of turns for a single male was significantly more frequent than for a single female; that communicators, regardless of sex, speak for a greater proportion of the total conversation are often males. This finding reveals the contrast to traditional notions of talkative women that is also found in formal setting of $\mathrm{O}^{\prime}$ Barr and Atkins.

\section{Table 1}

\begin{tabular}{|c|c|c|c|}
\hline Appearance frequency distribution & $\begin{array}{c}\text { Average number of } \\
\text { turns for a single man }\end{array}$ & $\begin{array}{c}\text { Average number of turns } \\
\text { for a single woman }\end{array}$ & $\%$ \\
\hline 117 & 29.25 & & 34 \\
\hline 225 & & 18.75 & 66 \\
\hline Total & & & $\mathbf{1 0 0}$ \\
\hline
\end{tabular}

(The official chat group for MAEL1-S/S, Sociolinguistics session 3 at 09.00/14.00.)

Table 2

\begin{tabular}{|c|c|c|c|}
\hline $\begin{array}{c}\text { Appearance frequency distribution } \\
\text { (times) }\end{array}$ & $\begin{array}{c}\text { Average number of } \\
\text { turns for a single man }\end{array}$ & $\begin{array}{c}\text { Average number of turns } \\
\text { for a single woman }\end{array}$ & $\%$ \\
\hline 46 & 11.5 & & 41 \\
\hline 67 & & 9.5 & 59 \\
\hline
\end{tabular}


International Journal of Social Science and Economic Research

ISSN: 2455-8834

Volume:05, Issue:10 "October 2020"

Total

113

100

(The official chat group for MAEL1, Pragmatics course)

The attributions of participants is briefly clarified and shown in tables 1 and 2. Firstly, in table 1 number of females (12) is three times more than males (4), if the number of talkers is divided by the number of turns, the result shows the average number of turns for a single man is 29.25 but the average number of turns for a single woman is lower with 18.75 and there is a female teacher. The frequency of appearance in times is distributed unequally. Men take control of the conversation quite prominently with 117 times, while women account for 225 times. If females take control of the room as frequent as males, the times they attribute must be: $(3 \times 117=351)$ not 225 as seen in table 1. Secondly, in table 2 when the numbers of females (7) is nearly twice as much as males (4) and a male teacher, with the average number of turns for a single man is 11.5 but the average number of turns for a single woman is also lower with 9.5 so the frequency men hold the floor still more than women with 46 times, take $41 \%$, women take 67 times with $59 \%$ but not as much as in table 1 .

Apart from the frequent appearance, men also show dominance throughout interruption and making question. Observing the conversations from two chat logs for seminar in Fronter, it is interesting to discover that although there are fewer men than women; men seem to take control the conversation with their typical language use. Men's role is more prominent and more powerful than women when they feel free to interrupt women in order to ask for further information or gain more understanding:

Man 1: $\quad$ scarlet? Who are you? or

Man 2: $\quad$ shall we change to Q2?

Man 1 saw the nickname of a female classmate scarlet, so he raises a question in direct way Who are you? He would like to gain information what exactly the female's name is. Man 2 is a bit different from man 1, while other classmates are discussing things for question 1; he interrupts by making a suggestion to move to question 2 : shall we change to $Q 2$ ?

\subsubsection{References}

Besides men's frequency of appearance, talking more often, they prefer to refer to a classmate, call out someone's name and take the place of the teacher in the room, for example:

Man 1: Sure female student, they are changed not only in lexicon, but also changes in pronunciation. 
International Journal of Social Science and Economic Research

ISSN: 2455-8834

Volume:05, Issue:10 "October 2020"

Man 2: formal doesn't always mean polite, female student.

Table 3A

\begin{tabular}{|c|c|c|c|}
\hline \multicolumn{2}{|c|}{$\begin{array}{c}\text { Averer to someone else } \\
\text { (times) }\end{array}$} & $\begin{array}{c}\text { Average number of } \\
\text { turns for a single man }\end{array}$ & for a single woman \\
\hline 18 & 4.5 & & 40.1 \\
\hline 26 & & & 59.9 \\
\hline Total & & & $\mathbf{1 0 0}$ \\
\hline
\end{tabular}

(The official chat group for MAEL1-S/S, Sociolinguistics session 3 at 09.00/14.00.)

\section{Chart 1}

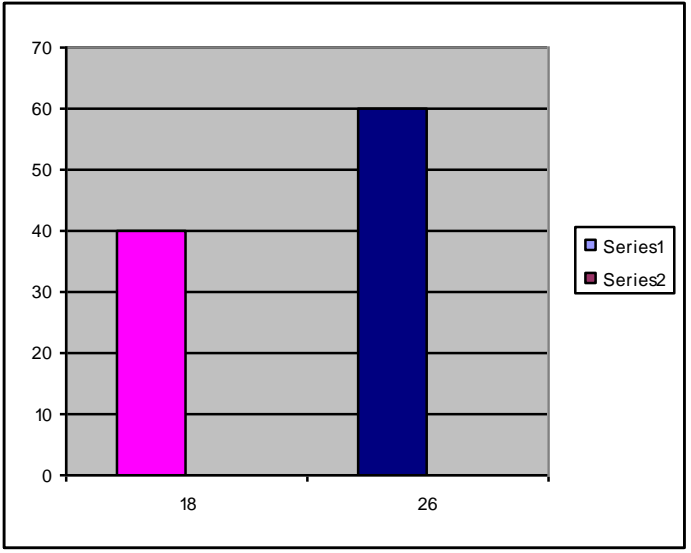

(Pink colour shows times and per cent belong to women, green colour shows men's)

Table 3B

\begin{tabular}{|l|l|l|}
\hline Refer to someone else & Number & $\%$ \\
\hline
\end{tabular}


International Journal of Social Science and Economic Research

ISSN: $2455-8834$

Volume:05, Issue:10 "October 2020"

\begin{tabular}{|l|c|c|}
\hline Female- Female (F-F) & 16 & 36.4 \\
Female- Male (F-M) & 10 & 22.7 \\
Male- Female (M-F) & 14 & 31.9 \\
Male- Male (M-M) & 4 & 9 \\
Total & 44 & $\mathbf{1 0 0}$ \\
\hline
\end{tabular}

(The official chat group for MAEL1-S/S,Sociolinguistics session 3 at 09.00/14.00.)

Men and women have different conversational styles. Men prefer to hold the floor and take charge of the role as a chairperson. From one-and-a half hour chat log, the reference is observed. The collected data includes 12 women and 4 men; the result was shown in table $3 \mathrm{~A}$ and chart 1 . Although the number of males (4) only accounts for a third the number of females (12) the frequency of words that they use to address females (18 times-in pink colour) accounts for $40.1 \%$, this is a bit less than female's which accounts for 59.9\% (26 times- in green colours). The table $3 \mathrm{~A}$ shows the average number of turns for a single man is 4.5 but the average number of turns for a single woman is twice much less than man's with 2.1 .

Taking a detail looks, in table 3B, the interactions between males and females, males with males and females with each other are shown clearly and quite interesting. With the same number of 4 males and 12 females the result is revealed as followed: females take the highest proportion (36.4\%) when they call other female's name, in contrast, males take the least proportion (9\%) when they call other male's name. They don't often refer to other males, but they quite prefer to call out females' names with $31.9 \%$, while females only account for $22.7 \%$ of referring to other females. For example:

Man: female Student is professional in using her husband language.

Man: male Student biology and physically.

Woman: because you and he can have mutual understanding, female Student

Woman: I see your point male student

Men's behavior tends to have higher status and the study revealed the prevalence of men in mixed-sex interactions. Men bear in mind a traditional image as the strong sex so when they have conversation with women they keep interrupting women by frequently calling women's names, explaining more about the discussed things and play a role as a teacher. Women also do the same but with a much lower rate, this apparent difference in usage reflect differences in 
status and in goals; power and status are distributed unequally, The figures in table 3A, 3B and chart 1 show styles that men frequently use in order to point out the dominance when having conversation with opposite sex as women. In addition, men are also natural in disagreeing with other speakers:

\section{No, female teacher}

Not really, female student

\subsection{Politeness strategies}

In communication, the differences are expressed by set of linguistic and conversational devices. Men see listening responses like "yes", "oh" as signals of agreement while women see them as indicating that the listener is attentive and the speaker should continue. So that women can be more cooperative by using polite forms such as: back- channel support, giving compliments and apologies, and saying thank you more often than men.

\subsubsection{Back channel support}

In conversation with other people, women pay much attention to the conversation by giving a lot of back-channel support such as (oh, really? yeah, hmm.) but men are the opposite; they produce less back-channel support. The cooperative style can be seen through the frequency of using back-channel support.

\section{Table 4}

\begin{tabular}{|c|c|c|c|}
\hline Back-channel support & $\begin{array}{c}\text { Average number of } \\
\text { turns for a single man }\end{array}$ & $\begin{array}{c}\text { Average number of turns } \\
\text { for a single woman }\end{array}$ & \\
\hline Yes (6) & 1.5 & & 17.6 \\
\hline Yes (28) & & & 82.4 \\
\hline Total & & & $\mathbf{1 0 0}$ \\
\hline
\end{tabular}

(The numbers in bracket show the frequency the words are repeated) 


\section{Chart 2}

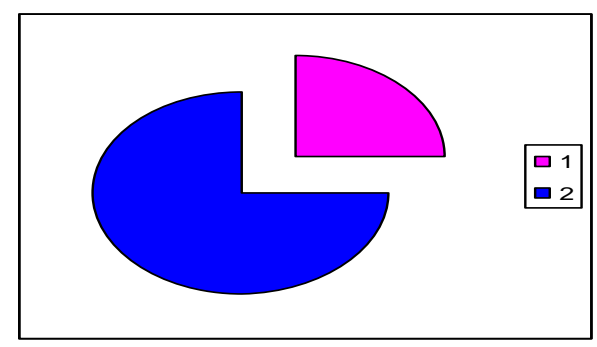

(Pink colour shows times and per cent belong to women, green colour shows men's)

The table 4 shows that women's back-channel support is different from men's back-channel support (in terms of frequency). The number of females (12) is three times more than male's (4) but the frequency they use back-channel support is much higher. The average number of turns for a single man is 1.5 but the average number of turns for a single woman is higher 2.3. Females use 28 times of "yes" account for $82.4 \%$ but males use only 6 times with $17.6 \%$. The chart 2 with two different colours, pink colour for women and green colour for men shows clearly different way of using back-channel support between men and women.

\section{Yes, I agree with student}

Women keep saying "yes" when they agree with the teacher or classmates, men, on the other hand; back-channel support are used not to support but to confirm, the way they say "yes" imply confirmation of information. For example:

\section{Yes, linguistically, teacher}

The way that men use back-channel support is similar to the case women use question tag.

\section{But you've been in Sweden longer than that, haven't you?}

A positive statement is followed by a negative question tag, the speaker here doesn't ask for information, but for confirmation of or agreement. The speaker is expecting a positive answer which has the same information as the questions.

\subsubsection{Compliments and Apologies}

Women's language behaviour is taken as the social dimension of politeness together with the social standards; to men this tendency is vice versa. No matter whether they are at home or in 
public, men do not focus much on devices to make a polite conversation, especially with apparent status equals. On the other hand, women, in general, are much more likely to express positive or negative politeness in interaction.

During mixed-sex conversations, women apologize more than men do, and they are also apologized to more often than the men. Taking detailed and close perusal of the data, findings are revealed that: in 7 transcripts, only two men apologise and they only do that when it needs to be done. The first man says sorry when he misunderstood the question and he gave the wrong answer.

\section{Yes, I see it. Sorry, the other way teacher}

The second man says sorry when he has a reason to leave the room early.

Sorry teacher, I have to see my new rector. It's his first day today. I'll see the chat log later

On the contrary, women are different. They say sorry more often; they are similar to men in case they say sorry when they have reasonable excuse such as:

\section{I'm sorry for my late}

However; they are far different from men when they say sorry for no reason. This phenomenon is seen as the way women would like to establish the relationship with speakers to be more polite and cooperative. For example:

\section{Sorry, my niece}

\section{So sorry}

With compliments, the study reveals different result from apologies. According to the theory, compliments are used more frequently by women than men. In return, they also receive compliments more often than men. However, searching carefully all the chat logs and transcriptions, there are no clues for this point but raising an unexpected form of saying thank you...

\subsubsection{Saying thank you}

Besides apologies, a special feature that arises from data: the forms of saying thank you in which women thank more often than men: 
International Journal of Social Science and Economic Research

ISSN: $2455-8834$

Volume:05, Issue:10 "October 2020"

\section{Table 5}

\begin{tabular}{|c|c|c|c|}
\hline Saying thank you (times) & $\begin{array}{c}\text { Average number of } \\
\text { turns for a single man }\end{array}$ & $\begin{array}{c}\text { Average number of turns } \\
\text { for a single woman }\end{array}$ & $\%$ \\
\hline 2 & 0.5 & & 20 \\
\hline 8 & & 0.7 & 80 \\
\hline Total $\mathbf{1 0}$ & & & $\mathbf{1 0 0}$ \\
\hline
\end{tabular}

(The official chat group for MAEL1-S/S, Sociolinguistics session 3 at 09.00/14.00, female teacher)

Table 6

\begin{tabular}{|c|c|c|c|}
\hline Saying thank you (times) & $\begin{array}{c}\text { Average number of } \\
\text { turns for a single man }\end{array}$ & $\begin{array}{c}\text { Average number of turns } \\
\text { for a single woman }\end{array}$ & $\%$ \\
\hline 2 & 0.5 & & 20 \\
\hline 8 & & 1.14 & 80 \\
\hline Total & & & $\mathbf{1 0 0}$ \\
\hline
\end{tabular}

(The official chat group for MAEL1, Pragmatics course, male teacher)

Making comparison between tables 5 and 6 , we can come to the conclusion that sex affects conversations a lot. It has been found that women have expressions that are different from men's. In a conversation with a female teacher (table 5), the number of women is three times more than men's (there are 12 women but only 4 men), the average number of turns for a single man is 0.5 . The times women say thank you are 8 times with $80 \%$ compare with 2 times of men, 20\% (equivalent to four times more than men's) and the average number of turns for a single woman stands at 0.7

Female: Yes, female teacher. Thank you for your explanation 


\section{International Journal of Social Science and Economic Research}

ISSN: $2455-8834$

Volume:05, Issue:10 "October 2020"

The woman prefers saying thank you as kind of way of pleasing the teacher in a polite way when the teacher has given a clear explanation. In the same way (table 6): the number of women is much less than ( 7 women) in comparing with the number of women in table 5 (12 women) but the frequency degree of saying thank you is the same (8 times), takes $80 \%$ while the number men is the same in both table 5 and table 6 ( 4 men) and they response the same ( 2 times), take $20 \%$ with both female and male teachers. Women are opposite with the average number of turns for a single woman at 1.14, they say thank you much more frequent when they discuss with a male teacher while the average number of turns for a single man is still the same with 0.5 (table 6).

\subsection{Changing the topic of conversation}

It is hypothesized that women and men speak differently and gender differences are found in topics they bring to conversations. While women's topics adhere to their family, children, husband and friends, the topics tend to be more personal. Men, on the other hand, are shown as the people who take more interest in impersonal topics such as: football, cars. However; the contrast between men and women is shown in this part: changing the topic of conversation.

The study shows that males tend to change subject more frequently than females. This difference may be well at the root of the conception that women chatter and talk too much, and may still trigger the same thought in some males. In this way a lowered estimation of women may arise. In order to investigate possible gender differences in topic shift and initiation in multiparty conversation, the data was collected from transcripts and chat logs and the episode shifts in each conversation were analyzed on the basis of gender distribution and type of shift. In addition, the finding of these groups were compared and discussed. The main result of this study was that the men initiated nearly 100 percent more shifts than women. The men took up more linguistic space and dominated the topical shifts in the conversation which indicates that gender differences in topic shift and initiation exists, a finding that is consistent with previous research within the field of gender and language. In conclusion, gender differences were found between how the women and the men participate in this study shifted and initiated topics. The men initiated more shifts than the women in the multiparty conversations. For example:

\section{Man 1: Can you drive with one hand?}

While all other students follow the topic that was discussing, they keep track, but this man responds to another man by raising a question. This question creates an implicature which is recognized as a particularized implicature. Particularized implicature can be defined as a conversational implicature that is derivable only in a specific context. Context is vital for both speakers and listeners to get the same interpretation. For example (Jonathan's lecture, 2006): 


\section{International Journal of Social Science and Economic Research}

ISSN: $2455-8834$

Volume:05, Issue:10 "October 2020"

\section{Some people believe in God}

The above example has a particularized implicature here means: you do or do not believe in God. The implicature need inference with reference to a special context. This kind of implicature depends on individual interpretation and also requires a lot of work to understand the conveyed meanings. As a result, Can you drive with one hand? conveys a message you cannot drive with only one hand, and the content seem to differ from the topic that is being discussed.

Take another example, another man raises a question that has different topic from discussed topic with the purpose to achieve more information.

\section{Man 2: What about the deadline of the $2^{\text {nd }}$ assignment?}

During the conversation, men continually change direction by referring to other topics or something different from the topic as a phenomenon of shift take. This matter is rare with women, the chat log also includes a different question from the topic being discussed made by a woman, but it is shown rather different from a man's:

\section{Woman: Is it ok for us to have the essay sample, male teacher?}

The woman would like to gain further information from a male teacher, so she raises an indirect question that is known as a form of polite request; however, they often obey the discussion strictly and they are quite afraid of losing the topic so that they develop the discussion gradually.

\section{Results.}

When applying the results to the theory, the study revealed both their strength and the weakness. For the strengths, the study shows clearly men's dominant role when they have conversation with women even there are fewer men than women, men also refer to women or call out women's names much more often than women do. Politeness strategies are also mentioned with the representatives of back-channel support, making apologies and saying thank you. The study ends with changing the topic of conversation. It could be said that the study covers some typical aspects to illustrate the differences between men and women in conversation.

However, the study still has some weaknesses: the theory affirms women are better at givingreceiving compliments than men, but the collected data does not have enough evidence to show the compliments as they are referred to in theoretical part. The data is collected from chat logs of seminars so language use of speakers represents a specific, academic and institutional type, this explains the lack of compliments. This matter is quite coincident with O' Barr and Atkins's research in their courtroom, women give and receive compliments more often than men but it is 


\section{International Journal of Social Science and Economic Research}

ISSN: $2455-8834$

Volume:05, Issue:10 "October 2020"

not always the case and it also depends on circumstances, context and the relationships between speakers in order to establish friendly cooperation.

The theory supplies some kinds of back-channel supports such as: oh, really? Yeah, hmm but the data includes only Yes which can be understood and replaced as Yeah. This matter can be explained as follows: English is being used worldwide and recognized as second language in many countries, but in Viet Nam English plays a role as foreign language. The subjects of the study are all Vietnamese- English speakers, despite their fluent ability in English speaking; they still face difficulties in using English language so they chose the simple one. This prevents speakers from showing completed communicative techniques as well as the language use in speech and it is also the disadvantage of the study. The shift of topic isn't shown clearly although men's frequent changes are shown when they have conversation with women.

The study gives the suggestion that it may be better to observe the shift of topic and givingreceiving compliments through spoken language in everyday life conversation not only in an institutional setting as in this essay to have comprehensive looks about the differences between men and women's speech in conversations.

Last but not least, it is cultural difference affecting English used by native speakers of Vietnamese. Women won their independence years ago, they have proved repeatedly that they are equal and often superior to men in almost every field such as doctor, lawyer, company director, scientist; however, they continue to be regarded as second-rate citizens with main role as children bearer and rear, typically in Viet Nam- an Asia country where there are old traditions and prejudice of women's role in society. This attitude remains and affects man's thought, so in conversation with women they are natural to interrupt, dominate and shift topics. On the contrary, women show very well their politeness, create attractive image when they speak to men despite suffering from men's backward opinion. They are generally more enthusiastic and polite especially when they speak to opposite sex.

\section{Conclusion}

The aim of the essay is to find out differences in language use between Vietnamese men and women in speech in English. This study is carried out to investigate linguistic differences between the sexes: what features speakers use to be typically male or female, whether men use language to dominate women, the techniques women apply in conversations and topical shifts between men and women's talks through chat logs and transcriptions of seminars.

Language and gender have a close relationship, the differences between men and women's speech has been the subject of many studies; this essay mainly focuses on the differences with 


\section{International Journal of Social Science and Economic Research}

ISSN: $2455-8834$

Volume:05, Issue:10 "October 2020"

three main aspects: male dominance, politeness strategies and changing the topic of conversation, through out both quantitative and qualitative research methods. The study revealed that women are better at maintaining relationships than men. Having conversations with men and women, women often develop the conversation by giving much back-channel support, apologies and saying thank you more often. In contrast, men prefer the dominating position when they have conversation with women that was seen as male dominance and topic shifts in conversations.

The subjects of the study come from Viet Nam, an Asia country where stereotypical ideas about woman with old thinking and inequality exist. As a result, Vietnamese men's and women's spoken English language is affected clearly by gender as well as environment surroundings. Women learn quickly from the art of conversation, and know how to remain conversation; however they are also affected by old prejudice about the women's role and equality that was shown through conversations with men.

Within the scope of the essay and limitations, the study cannot cover clearly the changing the topic in conversation between men and women and compliments. It should be better to have future studies in this area to give a comprehensive picture of topic shifts and giving-receiving compliments caused by gender differences.

For a deeper understanding of language and gender, it is necessary to take very detailed looks at gender behavior in different situations. Furthermore, more attention needs to be paid to social and linguistic differences within gender groups to improve the equality between men and women and understanding of how and when gender is involved in interaction and how it affects women's and men's ways of speaking. From that we can modify and adjust to establish a harmonious atmosphere between men's and women's conversation.

In conclusion, the difference between men and women and how the gender meanings relate to the positions and their images in society are important in language teaching. Knowing these differences, they remind us not to ignore the influence of the sex's participants in interaction; in addition it's a teacher's obligation to pay equal attention to both boys and girls in teaching. We also need to teach appropriate language forms and to teach in a suitable way to both men and women. We also need to help them to understand the distinction men and women bring to conversation, so that they can decode the speaking style of partner and avoid the unnecessary conflictions.

\section{References}

Brown, P.1980: How And Why Are Women More Polite. 


\section{International Journal of Social Science and Economic Research}

Brown, P. And S. Levinson. 1987: Politeness. Cambridge University Press. Cambridge

Coates, J. 1993: Women, Men And Language. 2nd. Longman. London. 1986

Coulmas, F. 2006: Sociolinguistics. $2^{\text {nd }}$. Cambridge University Press.

Crawford, M. 1995: Talking Differences. SAGE. London.

P. Eckert, S McConnell-Ginet. 2003. Language and Gender. Cambridge University Press.

Fishman, P.M.1978: Interaction- The Work Women Do. Rowley, Mass: Newburry House

Fishman, P.M. 1983: Interaction- The Work Women Do.

Gray, J. 1992: Men Are From Mars, Women Are From Venus. Harper Collins. New York.

Holmes, J. 1989: Sex Differences And Apologies-One Aspect Of Communicative Competence. Applied Linguistics. Oxford University Press.

Holmes, J. 1995. Women, Men and Politeness. Longman. London.

Klann \& Delius, G. 1987: Sex And Language. Berlin.

Lakoff, R .1975 : Language And Women's Place. Harper And Row. New York.

O’Barr, W.M. \& B.K. Atkins. 1980: Women's Language Or Powerless Language. New York.

Spender, D.1980: Man Made Language. Routledge And Kegan Paul. London.

Tannen, D. 1990: You Just Don't Understand- Women And Men In Conversation. Ballantine. New York.

Thomas, L. S. Wareing, I. Singh, J. Stilwell-Peccei, J. Thornborrow, J. Jones. 2004. Language Society and Power. Second Edition. Routledge. London. 86 -92.

Wolfson, N.1983: An Empirically Based Analysis of Complimenting in American English. Newburry House.

G. Yule. The Study of Language. Third Edition. Cambridge University Press. 222- 225.

http://www.llas.ac.uk/resources/goodpractice.aspx?resourceid=958 assessed on 2 November, 2007 
International Journal of Social Science and Economic Research

ISSN: 2455-8834

Volume:05, Issue:10 "October 2020"

http://ifa.amu.edu.pl/ Rrynicki/my_pres/my_pres_15.htm assessed on 22 October, 2007

https://fronter.du.se/ENC024(20062,50\%,Dagtid,Normal,Falun,omg1,-) Chat logs from seminar November 28 and December 5.

https://fronter.du.se/EN3009(HT07,25\%,BlanDat, Distans,Falun,NET) Chat logs from sociolinguistics session 3 for group MAEL!-S/S.

http://books.google.com.vn/books?id=ABra1vFQPOUC\&pg=PA93\&lpg=PA93\&dq=Male+dom inance-

+ in+conversation+thesis\&source=web\&ots=icmy4wnbEZ\&sig=_jinHldkTs92QQhKaFfwK3DD $\underline{\text { ZCo\&hl=en\#PPP1,M1 }}$

http://scholar.lib.vt.edu/theses/available/etd-08042002-171456/unrestricted/finalthesis1.pdf

https://fronter.du.se/ENC024(20062,50\%,Dagtid,Normal,Falun,omg1,-) Chat logs from seminar http://itre.cis.upenn.edu/ myl/languagelog/archives/000873.html

http://www.essays.se/essay/97088051d5/ 